\title{
Pengaruh Working Capital Turn Over Ratio Dan Current Ratio Terhadap Profitabilitas (Studi Kasus Pada PT. Gudang Garam Tbk Di Bursa Efek Periode 2011 - 2018)
}

\author{
${ }^{1}$ Minsyah Fuadi, ${ }^{2}$ Ahmadi Aidi \\ ${ }^{1,2}$ Institut Ilmu Sosial dan Management STIAMI Jakarta \\ ${ }^{1}$ minsyahfuadi@gmail.com, ${ }^{2}$ gadisrasela@gmail.com
}

\section{ARTICLE INFO}

\section{Keywords}

Working Capital Turn Over

Ratio,

Current Ratio,

$R O I$

\section{ABSTRACT}

The purpose of the research is to examine the influence of Working Capital Turn Over Ratio and Current Ratio on Profitability by using a measure of Return In Investment. Sampling from this study was taken from the financial statements of PT. Gudang Garam Tbk in the 2011-2018 period from the Indonesia Stock Exchange and data processed using the SPSS version 24 programs.

The results of this study indicate that Working Capital Turn Over Ratio has a positive and significant effect on Return In Investments based on the results of the $t$ test obtained Working Capital Turn Over Ratio has a tcount of 6.240 greater than the value of $t$-table which is 2.051. While the Current Ratio has a negative and opposite effect on the Return In Investment, with a t-count of 3,395 greater than the value of t-table that is 2,051. As the simultaneous Working Capital Turn Over and Current Ratio has an effect on Return In Investments with a significant 0,000 smaller than alpha $(\alpha)=0.05$.

\section{PENDAHULUAN}

\section{Latar Belakang}

Pada dasarnya setiap perusahaan, di dalam menjalankan usahanya, disemua bidang baik dalam bidang industri, jasa, perdangangan pasti mempunyai tujuan tertentu, yaitu mendapatkan laba yang sebesar-besarnya dengan menggunakan sumber daya yang telah dimiliki seefisien mungkin. Untuk mengetahui kinerja perusahaan dalam pencapaian laba, maka profitabilitas perusahaan harus diukur. Untuk mencapai laba yang diharapkan, manajemen harus mengambil kebijaksanaan yang tepat.

Return On Invesment (ROI) menunjukkan rasio yang digunakan oleh perusahaan untuk mengukur kemampuan perusahaan di dalam menghasilkan laba selama periode tertentu. Jumlah keuntungan (laba) yang diperoleh secara teratur serta kecendrungan yang meningkat merupakan faktor yang sangat penting dalam menilai rentabilitas atau profitabilitas suatu perusahaan. Bagi pimpinan, profitabilitas dapat digunakan sebagai tolak ukur untuk mengetahui berhasil atau tidaknya suatu perusahaan yang dipimpinnya, sedangkan bagi penanam modal dapat digunakan sebagai tolak ukur prospek modal yang ditanamkan dalam perusahaan tersebut.

Kegiatan-kegiatan yang dibiayai modal kerja antara lain adalah pembelian material/bahan baku, upah dan gaji karyawan serta berbagai macam biaya yang diharapkan dapat kembali dalam waktu singkat melalui hasil penjualan. Uang yang masuk dan bersumber dari hasil penjualan barang tersebut akan dikeluarkan kembali guna membiayai operasi perusahaan selanjutnya. Dengan demikian, dana tersebut akan berputar secara terus menerus setiap periodenya sepanjang hidup perusahaan.

\section{Perumusan Masalah}

Masalah yang akan diteliti selanjutnya dapat dirumuskan dalam bentuk pertanyaan sebagai berikut :

1. Berapa besar pengaruh Working Capital Turn Over Ratio terhadap Profitabilitas pada PT. Gudang Garam Tbk yang tercatat di BEI 2011 - 2018?

2. Berapa besar pengaruh Current Ratio terhadap Profitabilitas pada PT. Gudang Garam Tbk yang tercatat di BEI 2011 - 2018? 
3. Berapa besar pengaruh Working Capital Turn Over Ratio dan Current Ratio to Total secara Bersamasama (simultan) terhadapat Profitabilitas pada PT. Gudang Garam Tbk yang tercatat di BEI 2011 - 2018 ?

\section{Tujuan Penelitian}

Berdasarkan rumusan masalah diatas penelitian ini bertujuan untuk mengetahui seberapa besar :

1. Untuk menganalisa pengaruh Working Capital Turnover Ratio terhadap Profitabilitas pada PT. Gudang Garam Tbk yang tercatat di BEI 2011 - 2018.

2. Untuk menganalisa pengaruh Current Ratio terhadap Rasio Profitabilitas pada PT. Gudang Garam Tbk yang tercatat di BEI $2011-2018$.

3. Untuk menganalisa pengaruh Working Capital Turn Over Ratio dan Current Ratio secara Bersamasama (simultan) terhadapat Profitabilitas pada PT. Gudang Garam Tbk yang tercatat di Bursa Efek Indonesia 2011 - 2018.

\section{KAJIAN LITERATUR}

\section{Modal Kerja}

Pengertian modal kerja merupakan modal yang digunakan untuk melakukan kegiatan operasi perusahaan. Modal kerja diartikan sabagai investasi yang ditanamkan dalam aktiva lancar atau aktiva jangka pendek, seperti kas, bank, surat-surat berharga, piutang, persediaan, dan aktiva lancar lainnya, (Kasmir, 2018:250). Konsep modal kerja adalah konsep kuantitatif adalah jumlah keseluruhan aktiva lancar yang disebut juga modal kerja bruto (Gross Working Capital), konsep kualitatif merupakan kelebihan aktiva lancar di atas hutang lancar yang juga disebut modal kerja netto (Net Working Capital) dan Konsep fungsional merupakan konsep mengenai modal yang digunakan untuk menghasilkan Current Income.

Martono dan Hartijo (2007:76) menjelaskan ada 3 pilihan kebijakan modal kerja yang kemungkinan digunakan oleh perusahaan yaitu:

1) Kebijakan modal kerja konsevatif Kebijakan modal kerja konsevatif adalah kebijakan dimana perusahaan memodali sebagian modal kerja variabelnya dengan modal permanen, sedangkan sebagian modal kerja variabel lainnya dibelanjai dengan modal permanen.

2) Kebijakan Agresif

Pada kebijakan ini sebagian modal kerja permanen dibelanjai dengan sumber dana jangka panjang, sedangkan sebagian modal kerja permanen dan modal kerja variabel dibelanjai dengan sumber dana jangka pendek.

3) Kebijakan Moderat

Pada kebijakan ini aktiva yang bersifat tetap yaitu aktiva tetap dan modal kerja permanen dibelanjai dengan sumber dana jangka panjang, sedangkan modal kerja variabel dibelanjai dengan sumber dana jangka pendek.

Working Capital Turn Over Ratio adalah perbandingan antara penjualan dengan jumlah keseluruhan aktiva lancar. Dapat dihitung dengan:

\section{Likuiditas}

$\begin{array}{lc}\text { Working } & \text { Penjualan } \\ \text { Capital Turn } \\ \text { Over Ratio }=\end{array}$

Rasio yang digunakan untuk mengukur kemampuan perusahaan dalam memenuhi kewajiban keuangan jangka pendek yang berupa hutang-hutang jangka pendek. Rasio ini ditunjukkan dari besar kecilnya aktiva lancar.

Jika current ratio yang terlalu tinggi dianggap tidak baik karena dapat mengindikasi penimbunan kas, banyaknya piutang yang tidak tertagih dan penumpukan persediaan, namun jika current ratio rendah, relative lebih riskan, tetapi menunjukkan bahwa manajemen telah mengoperasikan aktiva lancar secara efektif (Fahmi, 2013:121).

Current Ratio adalah rasio yang membandingkan antara aktiva lancar yang dimiliki perusahaan dengan hutang jangka pendek (hutang lancar). Dapat dihitung dengan :

$$
\text { Current Ratio }=-\frac{\text { Aktiva lancar }}{\text { Hutang lancar }}
$$




\section{Profitabilitas}

Rasio Profitabilitas merupakan rasio untuk menilai kemampuan perusahaan dalam mencari keuntungan. Rasio ini juga memberikan ukuran efektivitas manajemen suatu perusahaan (Kasmir, 2018:196). Dalam penelitian pengukuran profitabilitas perusahaan yang digunakan adalah ROI digunakan untuk mengukur efektivitas perusahaan didalam menghasilkan keuntungan dengan memanfaatkan aktiva yang dimilikinya. Dapat dihitung dengan

$$
\text { ROI }=-\quad \frac{\text { Laba setelah bunga dan }}{\text { Pajak }}
$$

Hubungan Working Capital Turnover Ratio terhadap Profitabilitas (ROI)

Bila modal kerja perusahaan terlalu besar berarti ada sebagian dana yang mengganggur dan ini akan menurunkan profitabilitas perusahaan (Sutrisno, 2009:45). Demikian pula nilai modal kerja yang terlalu kecil akan ada resiko proses produksi perusahaan kemungkinan besar akan terganggu. Oleh karena itu, perlu ditentukan berapa besar kebutuhan modal kerja suatu perusahaan.

Modal kerja tinggi maka Profitabilitas juga tinggi (Martono dan Harjito, 2003).

\section{Hubungan Current Ratio terhadap Profitabilitas (ROI)}

Untuk menaksir tingkat keamanan (margin safety) kreditur jangka pendek atau kemampuan perusahaan membayar utang- utang jangka pendek. Rasio yang rendah mengindikasikan perusahaan kekurangan modal kerja untuk memenuhi kewajiban yang segera jatuh tempo, sedangkan rasio yang tinggi menandakan bahwa investasi yang dilakukan tidak menghasilkan return yang optimal (Saleem dan Rachman, 2011).

\section{Hipotesi}

Berdasarkan latar belakang masalah, teori- teori yang berkaitan, dan kerangka pemikiran penulis mengemukakan kesimpulan semantara adalah sebagai berikut :

1. Terdapat pengaruh Working Capital Turn Over Ratio terhadap Return on Investment pada PT. Gudang Garam Tbk.

2. Terdapat pengaruh Current Ratio terhadap Return on Investment pada PT. Gudang Garam Tbk.

3. Terdapat pengaruh Working Capital Turn Over Ratio dan Current Ratio secara bersama-sama (simultan) terhadap Return on Investment pada PT. Gudang Garam Tbk.

\section{Kerangka Pemikiran}

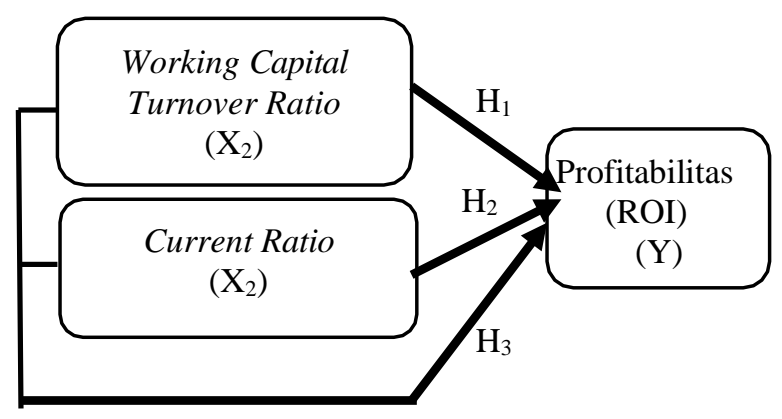

\section{METODE PENELITIAN}

\section{Pendekatan Penelitian}

Peneliti dalam melakukan penelitian menggunakan pendekatan kuantitatif dengan metode deksriptif. Penelitian deskriptif kuantitatif merupakan usaha sadar dan sistematis untuk memberikan jawaban terhadap suatu masalah dan/atau mendapatkan informasi lebih mendalam dan luas terhadap suatu fenomena dengan menggunakan tahap-tahap penelitian dengan pendekatan kuantitatif (Muri Yusuf, 2014:58).

\section{Teknik Pengumpulan Data}

Data yang dilakukan oleh peneliti menggunakan data sekunder. Data sekunder merupakan data yang tidak langsung memberikan data kepada pengumpulan data. Sumber data peneliti ini bersumber dari 
kepustakaan dan mengakses website www.idnfinancials.com

\section{Teknik Sampling}

Sampel dalam penelitian ini berasal dari laporan Keuangan Triwulan pada PT Gudang Garam Tbk pada periode 2011 - 2018. Sampel berjumlah 30 berasal dari jumlah 4 triwulan setiap tahun dikalikan selama 8 tahun buku, dikarenakan ada 2 data yang tidak valid, sampel berjumlah 30 kurang dari 10 maka digunakan sampel jenuh.

\section{Variabel Penelitian}

Variabel terikat yang digunakan dalam penelitian ini yaitu Return on Investment (ROI), sedangkan variabel bebasnya yaitu Working Capital Turn Over Ratio dan Current Ratio.

\section{Metode Analisis Data}

Rancangan analisis merupakan langkah - langkah yang dilakukan dalam menganalisis data dengan menggunakan software SPSS versi 24 dengan metode regresi linier berganda.

1. Analisis Statistik Deskriptif

Analisa deskriptif menggambarkan tentang ringkasan data-data penelitian seperti mean, standar deviasi, varian, modus. Juga dilakukan pengukuran untuk menggambarkan distribusi data apakah normal atau tidak dalam pembahasan ini akan dilakukan analisis deskriptif dengan gambaran data tentang jumlah data, minimum, maksimum, mean, dan standar deviasi.

\section{Uji Asumsi Klasik}

Regresi dengan metode estimasi Ordinary Least Square (OLS) akan memberikan hasil yang best linear unbiased estimator jika memenuhi semua asumsi klasik, (Ghozali, 2016:107). Dengan uji dibawah ini :

a. Uji Multikolinieritas

Uji multikolinieritas bertujuan untuk menguji apakah dalam model regresi terdapat korelasi antara variabel bebas.

b. Uji Heteroskedastisitas

Uji Heteroskedastisitas bertujuan menguji apakah dalam model regresi terjadi ketidaksamaan variance dari residual satu pengamatan ke pengamatan yang lain.

c. Uji Autokorelasi

Uji autokorelasi adalah untuk melihat apakah terjadi korelasi antara suatu periode $\mathrm{t}$ dengan periode sebelumnya (t-1).

d. Uji Normalitas

Uji normalitas bertujuan untuk menguji apakah dalam model regresi, variabel residual memiliki distribusi normal.

3. Uji Hipotesis

Uji hipotesis dalam penelitian ini menggunakan analisis regresi berganda adalah untuk mendapatkan tingkat akurasi dan dapat mengetahui apakah terdapat pengaruh yang signifikan antara variabel independent terhadap variabel dependent. Uji hipotesis dapat diperincikan sebagai berikut :

a Uji Regresi Linier Berganda Metode regresi linear berganda adalah suatu metode analisis yang dipergunakan untuk mengukur besarnya pengaruh variabel independent terhadap variabel dependen. Jadi analisis regresi ganda akan dilakukan bila jumlah variabel bebasnya minimal 2.

b. Uji Signifikan Parameter Individual (Uji Statistik t) Pengujian t stastik adalah pengujian terhadap masing- masing variabel independent. Uji t (cofficent) akan dapat menunjukkan pengaruh masing masing variabel independent terhadap variabel dependen.

c. Uji Koefisien Determinasi (R2) Analisis untuk mengetahui seberapa besar sumbangan atau kontribusi variabel independent terhadap variabel dependen.

d. Uji Siginifikan Simultan (Uji Statistik F)

tujuan untuk mengetahui apakah variable independen secara bersama-sama mempengaruhi variable dependennya. 


\section{ANALISIS DAN PEMBAHASAN}

Untuk memperoleh gambaran secara menyeluruh tentang variabel- variabel yang digunakan dalam penelitian ini baik variabel terikat maupun variabel bebas, maka dilakukan terlebih dahulu analisis secara statistik deskriptif yang mencakup nilai rata- rata (mean), standar deviasi, dan nilai ekstrim (nilai maksimum dan nilai minimum). Berikut ini rangkuman data statistik deskriptif dari variabel-variabel yang di gunakan dalam penelitian ini seperti yang ditunjukkan pada Tabel :

\begin{tabular}{|c|c|c|c|c|c|c|}
\hline $\begin{array}{c}\text { Variab } \\
\text { el }\end{array}$ & $\mathrm{N}$ & $\begin{array}{c}\text { Rang } \\
\mathrm{e}\end{array}$ & Min. & $\begin{array}{c}\text { Max } \\
\text { Mea } \\
\mathrm{n}\end{array}$ & $\begin{array}{c}\text { Std. } \\
\text { Deviati } \\
\text { on }\end{array}$ \\
\hline $\begin{array}{c}\text { WCT } \\
\text { O }\end{array}$ & 30 & 5,22 & $-\overline{48}$ & 2,74 & 1,20 & 1,40 \\
\hline CR & 30 & 2,17 & $-\overline{-}$ & 2,74 & 0,96 & 0,40 \\
\hline ROI & 30 & 10,18 & 0,22 & 7,11 & 3,50 & 3,45 \\
\hline
\end{tabular}

Pada tabel di atas dapat dilihat bahwa memperlihatkan bahwa variabel Return On Invesment (Y) memiliki nilai terendah sebesar -3,07 dan nilai tertinggi sebesar 7,11 dengan nilai rata-ratanya sebesar 3,50 dan standar deviasinya sebesar 3,45. Variabel Working Capital Turn Over Ratio (X1) memiliki nilai terendah sebesar -2,48 dan nilai tertinggi sebesar 2,74 dengan nilai rata-ratanya sebesar 1,20 dan standar deviasinya sebesar 1,40 . Variabel Current Ratio (X2) memiliki nilai terendah sebesar -0,22 dan dan nilai tertinggi sebesar 2,74 dengan nilai rata-ratanya sebesar 0,96 dan standar deviasinya sebesar 0,40 .

\begin{tabular}{|c|c|r|r|r|r|r|}
\hline \multicolumn{2}{|c|}{} & \multicolumn{2}{|c|}{$\begin{array}{c}\text { Unstandardized } \\
\text { Coefficients }\end{array}$} & $\begin{array}{c}\text { Standardized } \\
\text { Coefficients }\end{array}$ & $\mathrm{t}$ & Sig. \\
\cline { 2 - 7 } & B & $\begin{array}{c}\text { Std. } \\
\text { Error }\end{array}$ & Beta & & \\
\hline \multirow{2}{*}{1} & Constant & 4,894 & 1,071 & & 4,567 &, 000 \\
\cline { 2 - 8 } & WCTO & 1,686 &, 270 &, 684 & 6,240 &, 000 \\
\hline & CR & $-3,595$ &, 967 &,- 408 & $-3,717$ &, 001 \\
\hline
\end{tabular}

Berdasarkan tabel diatas, bahwa variabel Working Capital Turn Over Ratio mempunyai nilai thitung $=6,240$ sedangkan ttabel sebesar 2,05183. Maka disimpulkan bahwa nilai thitung lebih besar dari nilai ttabel, artinya menolak hipotesis awal dan menerima hipotesis alternative dan variabel Current Ratio $\left(\mathrm{X}_{2}\right)$ dengan nilai $t_{\text {hitung }}-3,717$, sedangkan $t_{\text {tabel }}$ pada signifikan 0,05 dan df 27 yaitu sebesar 2,05813. Maka nilai thitung lebih besar dri tabel, tetapi berlawanan arah dengan Return on Invesment, maka Current Ratio berpengaruh signifkan terhadap Return on Invesment.

\begin{tabular}{|c|c|l|l|l|c|c|}
\hline \multicolumn{2}{|c|}{ Model } & $\begin{array}{l}\text { Sum } \\
\text { Of } \\
\text { Squar } \\
\text { es }\end{array}$ & Df & $\begin{array}{l}\text { Mea } \\
\text { nqua } \\
\text { Sqe }\end{array}$ & F & Sig. \\
\hline \multirow{2}{*}{1} & $\begin{array}{l}\text { Regressi } \\
\text { on }\end{array}$ & 233,989 & 2 & $\begin{array}{r}116,99 \\
4\end{array}$ & $\begin{array}{c}28,30 \\
8\end{array}$ & $\begin{array}{c}, 000 \\
\text { b }\end{array}$ \\
\cline { 2 - 7 } & Residual & 111,589 & 27 & 4,133 & & \\
\cline { 2 - 7 } & Total & 345,578 & 29 & & & \\
\hline
\end{tabular}

Berdasarkan tabel di atas, hasil uji $\mathrm{F}$ dapat dilihat bahwa $\mathrm{F}_{\text {hitung }} 28,308$ dan nillai $\mathrm{F}_{\text {tabel }}$ sebesar 3,35 dengan signifikan 0,000 kurang dari 0,05. Sehingga dapat disimpulkan bahwa nilai $F_{\text {hitung }}$ lebih besar dari $\mathrm{F}_{\text {tabel }}$ sehingga dapat disimpulkan bahwa Working Capital Turn Over Ratio $\left(\mathrm{X}_{1}\right)$ dan Current Ratio $\left(\mathrm{X}_{2}\right)$ secara simultan bersama-sama berpengaruh signifikan terhadap ROI. 


\begin{tabular}{|c|c|c|c|c|c|}
\hline \multicolumn{2}{|c|}{ Model } & R & $\begin{array}{c}\text { R } \\
\text { squar } \\
\text { e }\end{array}$ & $\begin{array}{c}\text { Adjust } \\
\text { ed R } \\
\text { Square }\end{array}$ & $\begin{array}{c}\text { Std. } \\
\text { Error } \\
\text { Of the } \\
\text { Estima } \\
\text { te }\end{array}$ \\
\hline 1 & $\begin{array}{c}\text { WCT } \\
\text { O }\end{array}$ & $\begin{array}{c}, 715 \\
\text { a }\end{array}$ & 0,511 & 0,494 & 2,45534 \\
\cline { 2 - 6 } & CR & $\begin{array}{c}461 \\
\text { a }\end{array}$ & 0,212 & 0,184 & 3,11785 \\
\hline
\end{tabular}

1. Hasil penelitian ini menunjukan bahwa working capital turn over ratio berpengaruh parsial dan signifikan terhadap profitabilitas. Pengaruh tersebut ditunjukan dengan nilai dari $t_{\text {hitung }}=6,240$ sedangkan $t_{\text {tabel }}$ pada signifikan 0,05 yaitu sebesar 2,05183, maka nilai $t_{\text {hitung }}$ lebih besar dari $t_{\text {tabel }}$ dalam hal ini berarti variable Working Capital Turn Over Ratio (X1), berpengaruh signifikan terhadap Profitabilitas ROI (Y) pada perusahaan gudang garam Tbk yang terdaftar di Bursa Efek Indonesia pada tahun 2011 - 2018. Dengan koefisien regresi bernilai positif (+) sebesar 1,686 Tanda positif ini mempunyai arti bahwa setiap kenaikan Working Capital Turn Over Ratio akan diikuti peningkatan Return On Invesment .

2. Hasil penelitian ini menunjukan bahwa current ratio berpengaruh negatif dan tidak signifikan terhadap profitabilitas. Pengaruh tersebut ditunjukan dengan nilai dari $t_{\text {hitung }}=-3,717$ sedangkan $t_{\text {tabel }}$ pada signifikan 0,05 yaitu sebesar 2,05183, maka nilai $t_{\text {hitung }}$ lebih kecil dari $t_{\text {tabel }}$ dalam hal ini berarti variable Current Ratio (X2),memiliki pengaruh signifikan terhadap Return On Invesment pada perusahaan gudang garam Tbk yang terdaftar di Bursa Efek Indonesia pada tahun 2011 - 2018.

3. Hasil penelitian ini menunjukan bahwa Working Capital Turn Over Ratio dan Current Ratio berpengaruh positif dan signifikan terhadap Profitabilitas. Pengaruh tersebut dapat dilihat dari hasil Uji F dapat dilihat bahwa $F_{\text {hitung }}$ 28,308 dan nilai Ftabel sebesar 3,35 dengan signifikan 0,000 kurang dari 0,05. Sehingga dapat disimpulkan bahwa $\mathrm{H}_{0}$ ditolak, $\mathrm{H}_{1}$ diterima. Yang berarti antara Working Capital Turn Over Ratio $\left(\mathrm{X}_{1}\right)$ dan Current Ratio $\left(\mathrm{X}_{2}\right)$ secara simultan bersama sama berpengaruh positif dan signifikan terhadap Return On Invesment (Y) pada perusahaan gudang garam Tbk pada tahun 2011-2018.

\section{KESIMPULAN DAN SARAN}

\section{Kesimpulan}

Berdasarkan hasil penelitian dan pembahasan, maka dapat disimpulkan sebagai berikut :

1. Berdasarkan hasil uji koefisien determinasi, secara parsial bahwa Working Capital Turn Over Ratio (X1) mempengaruhi Return On Invesment sebesar 0,511 atau $51 \%$

2. Berdasarkan hasil uji koefisien determinasi, secara parsial bahwa Current Ratio (X2) mempengaruhi Return On Invesment sebesar 0,212 atau $21 \%$

3. Berdasarkan uji koefisien determinasi (R square), Working Capital Turn Over Ratio dan Current Ratio mempengaruhi Return On Invesment sebesar sebesar 0,677 atau 67\% dan sisanya 33\% dapat dijelaskan dengan variabel - variabel lain yang mempengaruhi Return On Invesment tetapi tidak diteliti oleh peneliti.

\section{Saran}

1. Bagi Peneliti Selanjutnya

a Mengembangkan penelitian dengan menambah variable lainnya seperti Current Liabilities to Total Assets to Total Ratio, sehingga hasil penelitian yang didapatkan lebih meluas dari penelitian sebelumnya.

b. Mengembangkan populasi dan sampel pada penelitian ini, misalnya menggunakan populasi dan sampel yang lebih luas dan banyak.

c. Peneliti dapat melakukan penelitian pada objek lainnya misalnya perusahaan lain yang bukan PT. Gudang Garam Tbk.

2. Bagi para praktisi pelaku investasi saham di PT Gudang Garam Tbk ini dapat dijadikan referensi dalam 
menganalisa salah satu perusahaan tembakau sebelum melakukan penanaman modal di pasar modal.

3. Bagi pemegang kepentingan perusahaan PT Gudang Garam Tbk yang dijadikan sebagai sampel dalam penelitian ini, penelitian ini dapat dijadikan sebagai bahan referensi untuk penentu kebijakan kedapannya dalam meningkatan keuntungan, sehingga dapat meningkatkan investor di perusahaan ini.

\section{DAFTAR PUSTAKA}

\section{Sumber Buku}

Darsono. 2006. Manajemen Keuangan Pendekatan Praktis, Kajian Pengembalian Keputusan Berbasis Analisis Laporan Keuangan. Jakarta: Piadit Media

Fahmi,Irfan. 2011. Analisis Laporan Keuangan. Cetakan Kesatu. Bandung: Afabeta

Harahap, Sofyan Syafri. 2013. Analisa Kritis Atas Laporan Keuangan, Jakarta: PT Raja Grafindo Persada Harahap, Sofyan Syafri. 2007. Analisa Kritis Atas Laporan Keuangan, Jakarta: PT Raja Grafindo Persada

Horme, Van James C. 2005. Prinsip-prinsip Manajemen Keuangan. Edisi Kedua belas. Jakarta: Salemba Empat

Jumingan, 2005. Analisis Laporan Keuangan.Surakarta: Bumi Aksara

Jumingan, 2005. Analisis Laporan Keuangan. Cetakan Ketiga Jakarta: PT Bumi Aksara

Kasmir. 2013. Analisis Laporan Keuangan. Cetakan Keenam. Jakarta: PT Raja Grafindo Persada

Kasmir. 2009. Analisis Laporan Keuangan. Jakarta: PT Raja Grafindo Persada

Manullang, Marihot dan Sinaga, Dearlina. 2005. Pengantar Manajemen Keuangan Yogyakarta: Andi Offset

Martono dan Harjito, D. Agus. 2007. Manajemen Keuangan. Yogyakarta: Ekonisia

Martono dan Harjito, D. Agus. 2003. Manajemen Keuangan. Yogyakarta: Ekonisia

Riyanto, Bambang. 2008. Dasar-dasar Pembelanjaan Perusahaan. Yogyakarta: penerbit GPEE

Samryn, L.M. 2011. Pengantar Akuntansi. Edisi satu buku 1. Jakarta: Rajawali Pers.

Sartono, Agus. 2010. Manajemen Keuangan Teori dan Aplikasi. Yogyakarta: BPPE

Sawir. Agnes. 2005. Analisis Kinerja Laporan Keuangan dan Perencanaan Keuangan Perusahaan. Cetakan Kedua: PT. Gramedia Pustaka

Soepardi, Eddy Mulyadi, Sigit Edy Surono, Panpon Eka Sejati dan Junjungan, 2015. Analisis Likuiditas dan Leverage terhadap Profitabiltas Perusahaan yang terdaftar di Bursa Efek Indonesia. Jurnal pada Magister Manajemen Universitas Pakuan, Hal 2-10

Sugiono. 2010. Metode Penelitian Kuantitatif Kualitatif dan R\&D. Bandung: Alfabeta

Sujarweni, Wiratna. 2017. Analisa Laporan Keuangan. Yogyakarta: Pustaka Baru Press

Sujarweni, Wiratna. 2016. Kupas Tuntas Penelitian Akuntansi dengan SPSS. Yogyakarta: Pustaka Baru Press

Sutrisno. 2009. Manajemen Keuangan Teori, Konsep dan Aplikasi. Yogyakarta: Ekonisia

Yusuf, A. Muri. 2017. Metode Peneltian Kuantitatif Kualitatif \& Penelitian Gabungan. Jakarta: Kencana

Sumber Internet https://www.idx.co.id https://www.idnfinancials.com 